НАУКОВИЙ ВІСНИК

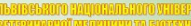

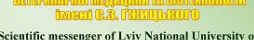

ientific messegger of Lviv National Universit
Veterinary Medicine and Biotectinologies

trits

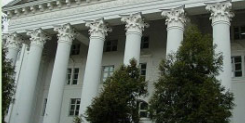

Том 21 № 91

2019
Науковий вісник Дьвівського національного університету ветеринарної медицини та біотехнологій імені С.3. Гжицького. Серія: Сільськогосподарські науки

Scientific Messenger of Lviv National University of Veterinary Medicine and Biotechnologies. Series: Agricultural sciences

UDC 636.598: 636,082

\title{
Reproductive and feather-fluff qualities of the obroshyno breed geese group in the third generation with blood of geese of great gray and legart breeds
}

\author{
M. Petriv ${ }^{1}$, L. Ferenc ${ }^{1}$, O. Sloboda ${ }^{2}$ \\ ${ }^{1}$ Institute of Agriculture of Carpathian Region NAAS, Obroshyno, Ukraine \\ ${ }^{2}$ Stepan Gzhytskyi National University of Veterinary Medicine and Biotechnologies Lviv, Ukraine
}

\section{Article info}

Received 11.09.2019

Received in revised form 11.10 .2019

Accepted 12.10.2019

Institute of Agriculture of Carpathian region of Ukraine

NAAS, Grushevskogo Str., 5

Obroshyno, 81115, Ukraine.

Tel.: (032) 239-61-70

E-mail:lvferenz@gmail.com

Stepan Gzhytskyi National University of Veterinary Medicine and Biotechnologies Lviv, Pekarska Str., 50, Lviv, 79010, Ukraine.

Tel.: +38-067-261-66-87 E-mail:oleh.sloboda@gmail.com
Petriv, M., Ferenc, L., \& Sloboda, O. (2019). Reproductive and feather-fluff qualities of the obroshyno breed geese group in the third generation with blood of geese of great gray and legart breeds. Scientific Messenger of Lviv National University of Veterinary Medicine and Biotechnologies. Series: Agricultural sciences, 21(91), 71-75. doi: 10.32718/nvlvet-a9112

We set the aim to study the effect of the blood influx of large gray geese and legart geese breeds on the productive qualities of the obroshyno breed group of geese in the third generation) and the legarts that have been highlighted in our previous publications. With the descendants of these crosses breeding and breeding work was conducted in the direction of breeding and productive qualities improvement. For our research, four groups of 50 birds each were compiled from the livestock of geese, which were kept separately for the breeding and egg laying periods (from January to May) to ensure proper feeding and retention. The average geese live weight at the beginning of oviposition were: females $O S-6.25 \mathrm{~kg}, O B-6.35, O S$ q $(O S$

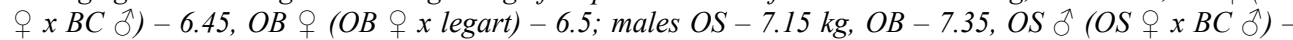
$7.45, O B$ ते $(O B+$ x legart $\hat{0})-7.50 \mathrm{~kg}$. The duration of oviposition was higher in purebred geese (groups I and III) compared to domestic geese (groups II and IV). The average oviposition of the group I geese was highest - $41.0 \mathrm{pcs} / \mathrm{head}$ and was dominated by the group II geese by $1.2 \%$. The weight of OS of geese of group III amounted to $40.6 \mathrm{pcs} / \mathrm{head}$ and was dominated by local geese of group IV by $2.9 \%$. However, domestic geese (groups II and IV), by weight of eggs, outperformed purebred geese (groups I and III) by 2.1 and $4.5 \%$, respectively. The study of incubation qualities of eggs shows that the fertilization in purebred $A B$ and OS geese (groups I and III) was $83.9 \%$ and $83.0 \%$, and the analogues from II and IV groups prevailed by 0.4 and $0.5 \%$, respectively. The higher hatchability of the geese was in hybrid geese (groups II and IV) than in purebred OBS and geese OS (groups I and III). On the basis of the conducted researches the following conclusions were made: 1. The productivity of geese AB of the breed group (group I) is characterized by the following performance indicators: oviposition - 40.6 pcs. per head; egg weight $153.2 \mathrm{~g}$; fertilization $-83.5 \%$; deductibility - 71.8\%; live weight of geese at 9 weeks of age - males $4.05 \mathrm{~kg}$, females $-3.67 \mathrm{~kg}$; conservation - 87.0\%. 2. Local geese of OB x legart (group II) had lower productivity rates: by $2.9 \%$, they had a low fertility rate of $0.5 \%$; fertility $-1.5 \%$; live weight of geese at 9 weeks of age: males $-6.7 \%$, females $-4.6 \%$; conservation $-2.0 \%$; at higher egg mass by $2.1 \% .3$. Geese of the OS of the breed group (group III) are characterized by the following performance indicators: oviposition - 40.6 pcs. per head; egg weight $-153.2 \mathrm{~g}$; fertilization $-83.0 \%$; excretion rate $-71.0 \%$; live weight of geese at 9 weeks of age - males $4.05 \mathrm{~kg}$, females - $3.67 \mathrm{~kg}$; conservation-87.0\%. 4. Local geese OS x BS (group IV) are characterized by lower indicators, respectively: with a yield of $2.9 \%$, higher fertilization $-0.5 \%$; with a yield of $1.5 \%$; live weight of geese at 9 weeks of age: males $-6.7 \%$, females $-4.6 \%$; conservation - by $2.0 \%$; at higher egg mass by $4.5 \%$.

Key words: obroshyno gray and white geese, legartas, reproductive qualities, oviposition, fertilization, incubation qualities, feather qualities.

\section{Репродуктивні та перо-пухові якості оброшинської породної групи гусей в III поколінні при прилитті крові гусей великої сірої та породи легарт}

\author{
М.Д. Петрів ${ }^{1}$, Л.В. Ференц ${ }^{1}$, О.М. Слобода ${ }^{2}$
}


${ }^{1}$ Інститут сільського господарства Карпатського регіону НААНУ, с. Оброшино, Україна

${ }^{2}$ Львівський національний університет ветеринарної медицини та біотехнологій імені С.З. Гжицького, м. Львів, Україна

Нами ставилось завдання вивчити вплив прилиття крові гусей великої сірої породи та породи легарт на продуктивні якості оброшинської породної групи гусей в III поколінні. В минулі роки ми проводили схрещування оброшинських сірих (ОС) і оброшинських білих гусей (ОБ) відповідно з великими сірими (BC) та легартами, що відображено в наших попередніх публікаиіях. 3 нащадками від иих схрещувань проводилася селекційно-племінна робота в напрямку покращення племінних $і$ продуктивних якостей. Для проведення досліджень нами із поголів'я гусей сформовано чотири групи птиці по 50 голів в кожній, які на період парування та яйцекладки (з січня по травень) утримувалися роздільно із забезпеченням належного рівня годівлі та режиму утримання. Вста-

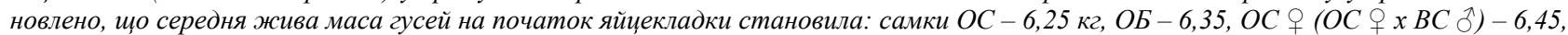

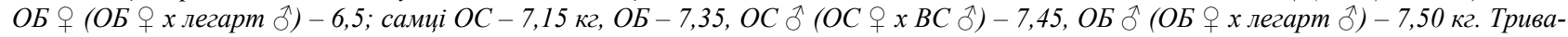
лість яйцекладки була вищою у чистопородних гусей (групи I і III), в порівнянні з помісними гусьми (групи II і IV). Середня несучість ОБ гусок I групи була найвищою - 41,0 шт/гол і переважала помісних гусей II групи на 1,2\%. Несучість ОС гусок III групи становила - 40,6 шт/гол і переважала помісних гусей IV групи на 2,9\%. Проте, помісні гуси (групи II і IV) за масою яєць переважали чистопородних гусей (групи I і III) на 2, 1 і 4,5\% відповідно. Вивчення інкубаційних якостей яєиь свідчить, що запліднюваність у чистопородних ОБ та ОС гусей (групи I і III) становила 83,9\% та 83,0\%, а аналоги з II і IV груп переважали на 0,4 та 0,5\% відповідно. Вища виводимість гусенят була у гібридних гусей (групи II і IV) ніж у чистопородних ОБ та ОС гусей (групи I $i$ III). На основі проведених досліджень зроблено наступні висновки: 1. Продуктивність гусей ОБ породної групи (I група) характеризується такими показниками продуктивності: несучість - 40,6 шт. на голову; маса яйия - 153,2 2; запліднюваність - 83,5\%; виводимість - 71,8\%; жива маса гусей в 9-тижневому віці - самиі 4,05 к2, самки - 3,67 кг; збереженість - 87,0\%. 2. Помісні гуси ОБ х легарт (II група) мали нижчі показники продуктивності: за несучістю на 2,9\%, проте мали вищу запліднюваність - 0,5\%; виводимість - 1,5\%; живу масу гусей в 9-тижневому віщі: самиі - на 6,7\%, самки - 4,6\%; збереженістю - 2,0\%; при вищій масі яйия на 2,1\%. 3. Гуси ОС породної групи (III група) характеризуються такими показниками продуктивності: несучість - 40,6 шт. на голову; маса яйия - 153,2 2; запліднюваність - 83,0\%; виводимість - 71,0\%; жива маса гусей в 9-тижневому віиі - самиі 4,05 кг, самки - 3,67 кг; збереженість - 87,0\%. 4. Помісні гуси ОС х ВС (IV група) характеризуються відповідно нижчими показниками: за несучістю на 2,9\%, вищою запліднюваністю - 0,5\%; виводимістю - 1,5\%; живою масою гусей в 9-тижневому віџі: самиі - на 6,7\%, самки - 4,6\%; збереженістю - на 2,0\%; при вищій масі яйџя на 4,5\%.

Ключові слова: оброшинські сірі та білі гуси, легарти, репродуктивні якості, несучість, запліднюваність, інкубаційні якості, якість пір'я.

\section{Вступ}

У гусівництві України формується м'ясний напрямок, з використанням птиці з генетично обумовленими ознаками: інтенсивним ростом в ранньому віці, здатністю до відгодівлі на жирну печінку, підвищениим виходом пера та пуху прижиттєвої обскубки (Aghdam Shahryar \& Lotfi, 2015; Orishchuk et al., 2017). Удосконалення вітчизняного генетичного матеріалу гусей можливе при наявності селекційних програм 3 використанням ефективних селекційних методів, в тому числі і схрещування. За багато років праці в Інституті була створена породна група оброшинських сірих та білих гусей, яка виведена методом схрещування місцевих білих, китайських сірих і великих сірих гусей і поєднує в собі ознаки всіх цих порід: значну кількість пуху і пір'я білих гусей з життєздатністю, невибагливістю до корму, ніжністю м'яса i високою несучістю китайських, а також 3 великою живою масою, скороспілістю і добрими м'ясними якостями великих сірих гусей, які характеризуються високими продуктивними якостями і доброю пристосованістю до природно кліматичних умов зони розведення (Sedilo, 2014; Petriv et al., 2018).

Актуальність теми. В даний час є висока потреба в породах добре пристосованих до місцевих умов утримання, з високою інтенсивністю росту та добрими відгодівельними якостями. Створення нових порід високопродуктивної птиці неможливе без використання генетичної розмаїтості, властивої різним породам. Інтенсивна селекція за основними продуктивними показниками обов'язково призводить до ослаблення ознак, які характеризують фізіологічний стан птиці, іiі життєздатність. В процесі спеціалізованої селек- ції посилюються депресивні явища (Solé et al., 2016; Zaplatynsky, 2017). Отже, необхідно зберігати резерв спадкової мінливості - генофонд, з якого можна періодично брати генетичний матеріал, котрий втрачається в процесі інтенсивної селекції у спеціалізованих порід. Вивчення специфіки відтворення порід в комплексі з ознаками продуктивності дозволить прослідкувати процеси які призводять до депресії ознак і удосконалити прийоми відтворення генофонду сільськогосподарської птиці (Sloboda \& Sloboda, 2018).

Гусей традиційно розводять заради м'яса, жиру, перо-пухової сировини та великої жирної печінки.

Гусяча перо-пухова сировина має попит на світовому ринку. Близько 95\% виробництва (приблизно 87 тис. т) припадає на Китай. В Україні виробляється за рік близько 10-12 т перо-пухової сировини прижиттевого обскубування. Світові ціни на гусячий пух становлять 100-130 дол. США за 1 кг, на перо-пухову сировину з вмістом пуху близько 30\% - 50-58 дол. США за 1 кг. Однак в Україні вони значно нижчі та становлять залежно від якості 100-300 грн/кг.

В даний час є висока потреба в породах добре пристосованих до місцевих умов утримання, 3 високою інтенсивністю росту та добрими відгодівельними якостями. Створення нових порід високопродуктивної птиці неможливе без використання генетичної розмаїтості, властивої різним породам. Інтенсивна селекція за основними продуктивними показниками обов'язково призводить до ослаблення ознак, які характеризують фізіологічний стан птиці, iї життєздатність (Petriv, 2016).

Мета роботи В процесі спеціалізованої селекції посилюються депресивні явища, отже, необхідно зберігати резерв спадкової мінливості - генофонд, з якого 
можна періодично брати генетичний матеріал, котрий втрачається в процесі інтенсивної селекції у спеціалізованих порід.

Вивчення нами специфіки відтворення порід в комплексі з ознаками продуктивності дозволить прослідкувати процеси які призводять до депресії ознак і вдосконалити прийоми відтворення генофонду сільськогосподарської птиці, зокрема гусей (Bozhko, 1989; Petriv et al., 2017).

В жодному племінному господарстві України не займаються розведенням гусей оброшинської селекції. Отже, збереження, вдосконалення і нарощування поголів'я цієї птиці та розробка нових моделей ведення гусівництва у господарствах різних форм власності $\epsilon$ актуальним завданням науки і практики на сьогоднішній день.

Універсальна продуктивність, невибагливість до умов утримання, здатність споживати об'ємисті корми з високим рівнем клітковини - якості, що підтверджують доцільність розведення гусей.

Наша робота базується на попередніх дослідженнях, які переконливо довели, що в умовах західного регіону гуси оброшинської селекції добре пристосовані до місцевих умов годівлі та утримання і з ними потрібно проводити селекційну роботу в напрямку збереження, вдосконалення та розширенняїх популяцiï.

\section{Матеріал і методи досліджень}

У 2018 році нами ставилось завдання вивчити вплив прилиття крові гусей великої сірої та породи легарт на продуктивні якості оброшинської породної групи гусей в III поколінні та зберегти генофонд оброшинських гусей.

Дослідження проводилися в лабораторії дрібного тваринництва ІСГКР НААН та ДП ДГ “Миклашів”.

Основним методом племінної роботи є відбір і підбір особин $з$ високими продуктивними якостями 3 метою одержання однотипної птиці, яка б відповідала запланованим параметрам продуктивності. В минулі роки нами проводились схрещування оброшинських сірих і білих гусей відповідно з великими сірими та легартами. 3 нащадками від цих схрещувань проводи- лася селекційно-племінна робота в напрямку покращення племінних і продуктивних якостей.

Селекційна робота проводилася шляхом індивідуально-масового відбору, спрямована на закріплення стандартних для кожної породної групи ознак. Перед початком племінного періоду самці та самки всіх породних груп були індивідуально оцінені за екстер'єром, типовістю оперення, живою масою. Протягом продуктивного періоду на груповому рівні проводився облік несучості, заплідненості, виводимості яєць, виводу молодняку. В добовому віці проведено жорсткий відбір гусенят за екстер'єром. В процесі вирощування гусенят 3 живою масою, меншою середнього значення по стаду, у 9- та 26-тижневому віці було вибраковано. При цьому за зовнішніми ознаками було проведено відбір гусей 3 добре розвинутими м'ясними формами при відсутності у них дефектів екстер'єру та визначалися проміри статей тіла асоційовані з м'ясними формами. В процесі вирощування було враховано збереженість молодняку до 9тижневого віку.

3 поголів'я гусей сформовано чотири групи птиці по 50 голів в кожній, які на період парування та яйцекладки (з січня по травень) утримувалися роздільно із забезпеченням належного рівня годівлі та режиму утримання. Облік несучості проводився щоденно 3 вирахуванням індексу форми яєць шляхом лінійного вимірювання та зважування і відбору за цим показником та масою їх для інкубації. Нагромадження інкубаційних яєць та контроль за їх зберіганням проводився кожні 14 днів, після чого вони відправлялися на інкубацію (Vlizlo, 2012).

Молодняк, починаючи з одноденного віку був позначений і поставлений на роздільне вирощування згідно з генотипом. Годівлю до 3-тижневого віку, здійснювали комбікормом. До 21-тижневого віку досліджувався ріст та розвиток гусенят (подекадне зважування та взяття основних промірів статей тіла).

У 2018 селекційна робота проводилася із застосуванням внутрішньопородного розведення оброшинських сірих і білих гусей в III поколінні, отриманих в попередні роки, шляхом індивідуально-масового відбору та спрямована на закріплення стандартних ознак (Petriv et al., 2018).

\section{Таблиця 1}

Схема досліду

\begin{tabular}{|c|c|c|c|c|}
\hline & \multicolumn{4}{|c|}{ Породи і породні групи } \\
\hline & ОБ $\hat{\sigma}$ & ОБ x легарт ô (III покоління) & $\mathrm{OC} \mathrm{O}^{-1}$ & ОС x ВC ठ̂ (III покоління) \\
\hline ОБ 우 & $\mathrm{X}$ & & & \\
\hline ОБ х легарт + (III покоління) & & $\mathrm{X}$ & & \\
\hline $\mathrm{OC}$ 우 & & & $\mathrm{X}$ & \\
\hline ОС x BC $q$ (III покоління) & & & & $X$ \\
\hline
\end{tabular}

Примітка: ОБ - оброшинська біла; ОС - оброшинська сіра; ВС - велика сіра

Поголів'я помісних гусей, не задіяних у дослідженнях в 2018 році утримувалось окремо і отриманий від них молодняк реалізовувався господарствам та населенню.

\section{Результати та їх обговорення}

Середня жива маса гусей на початок яйцекладки становила: самки ОС - 6,25 кг, ОБ - 6,35, ОС $q$ (OC $q$

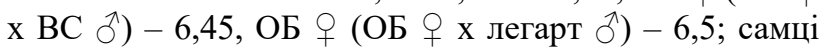




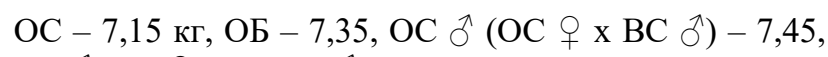
ОБ $\widehat{\jmath}($ ОБ + х легарт $\precsim)-7,50$ кг.

Несучість - важлива ознака продуктивності, яка залежить від породних та індивідуальних особливостей птиці і умов утримання та годівлі.

Таблиця 2

Несучість та інкубаційні показники яєць, $\mathrm{n}=50$
Одним з важливих показників в оцінці продуктивних і племінних якостей $\epsilon$ маса яйця, яка пов'язана із статевою зрілістю, віком, несучістю, інкубаційними якостями яєць і живою масою в одноденному віці.

\begin{tabular}{|c|c|c|c|c|}
\hline \multirow{2}{*}{ Показники } & \multicolumn{4}{|c|}{ Група гусей } \\
\hline & $\mathrm{I}$ & II & III & IV \\
\hline Тривалість яйцекладки, днів & $103 \pm 4,60$ & $100 \pm 5,20$ & $97 \pm 4,80$ & $93 \pm 5,40$ \\
\hline Середня несучість гусок, шт. яєць & $41,0 \pm 1,10$ & $40,5 \pm 1,80$ & $40,6 \pm 2,10$ & $39,8 \pm 1,30$ \\
\hline Середня маса яйця, г & $159,1 \pm 2,10$ & $162,4 \pm 2,90$ & $153,2 \pm 3,0$ & $160,1 \pm 2,30$ \\
\hline Довжина яйця, мм & $84,0 \pm 0,15$ & $84,4 \pm 0,20$ & $83,2 \pm 0,19$ & $84,1 \pm 0,13$ \\
\hline Ширина яйця, мм & $56,5 \pm 0,12$ & $56,1 \pm 0,18$ & $56,4 \pm 0,16$ & $56,2 \pm 0,11$ \\
\hline Індекс форми, \% & 67,3 & 66,5 & 67,5 & 66,8 \\
\hline Міцність шкаралупи, кг/мм² & 2,13 & 2,17 & 2,15 & 2,16 \\
\hline Товщина шкаралупи, мм & 0,43 & 0,42 & 0,44 & 0,45 \\
\hline
\end{tabular}

Аналізуючи дані табл. 2, видно, що тривалість яйцекладки була вищою у чистопородних гусей (групи I i III), в порівнянні з помісними гусьми (групи II і IV). Середня несучість ОБ гусок I групи була найвищою 41,0 шт/гол і переважала помісних гусей II групи на 1,2\%. Несучість ОС гусок III групи становила - 40,6 шт/гол і переважала помісних гусей IV групи на 2,9\%. Проте, помісні гуси (групи II і IV) за масою яєць пе- реважали чистопородних гусей (групи I і III) на 2,1 i 4,5\% відповідно.

Вивчення інкубаційних якостей яєць (табл. 3) свідчить, що запліднюваність у чистопородних ОБ та ОС гусей (групи I і III) становила $83,9 \%$ та $83,0 \%$, а аналоги з II i IV груп переважали на 0,4 та 0,5\% відповідно. Вища виводимість гусенят була у гібридних гусей (групи II i IV) ніж у чистопородних ОБ та ОС гусей (групи I і III).

Таблиця 3

Результати інкубації яєць

\begin{tabular}{ccccc}
\hline Група & Запліднюваність, \% & Задохлики, \% & Вивід гусенят, \% & Збереженість, \% \\
\hline I & 83,9 & 9,2 & 75,1 & 92,0 \\
II & 84,3 & 7,4 & 76,5 & 91,8 \\
III & 83,0 & 12,5 & 71,0 & 87,0 \\
IV & 83,5 & 10,5 & 72,5 & 89,0 \\
\hline
\end{tabular}

Отже, за результатами показників запліднюваності та збереженості переважала I і II група (табл. 3).
Вивчення росту і розвитку пір'я гусей на різних стадіях онтогенезу є одним з інформативних показників племінних і продуктивних якостей птиці.

Таблиця 4

Фракційний склад перо-пухової сировини молодняка гусей, \%

\begin{tabular}{|c|c|c|c|c|c|}
\hline \multirow{2}{*}{$\begin{array}{c}\text { Групи } \\
\text { гусей }\end{array}$} & \multicolumn{2}{|c|}{ Перо } & \multicolumn{2}{|c|}{ Пух } & \multirow{2}{*}{$\begin{array}{c}\text { Засміченість, } \\
\%\end{array}$} \\
\hline & Зріле & Незріле & Зріле & Незріле & \\
\hline \multicolumn{6}{|c|}{11 тижнів } \\
\hline I & 66,8 & 7,5 & 13,7 & 5,2 & 5,8 \\
\hline II & 67,2 & 8,7 & 14,1 & 4,6 & 5,4 \\
\hline III & 68,0 & 6,3 & 15,6 & 4,8 & 5,3 \\
\hline IV & 68,6 & 7,1 & 15,3 & 4,1 & 4,9 \\
\hline \multicolumn{6}{|c|}{18 тижнів } \\
\hline I & 60,9 & 2,4 & 33,4 & 0,8 & 2,5 \\
\hline II & 58,7 & 3,3 & 35,8 & 1,2 & 1,0 \\
\hline III & 59,5 & 1,2 & 34,7 & 2,2 & 2,4 \\
\hline IV & 61,0 & 2,3 & 32,2 & 1,7 & 2,8 \\
\hline
\end{tabular}

Аналізуючи наведені дані видно, що вміст пуху в перо-пуховій сировині одержаній при першому скубанні невисокий і становить 13,7-15,6\%. При другому скубанні вміст пуху зростає більш ніж у два рази і складає 32,2-35,8\%. Оброшинські сірі гуси мають дещо вищі показники пера і пуху порівняно з оброшинськими білими (але, а в той же час їх сировина містила більше незрілого пера і пуху) статистично 
вірогідної різниці між групами за вмістом перопухової сировини нами не виявлено. Але оброшинські сірі проявляють тенденцію до покращення своїх перопухових якостей.

\section{Висновки}

1. Продуктивність гусей оброшинської білої породної групи (І група) характеризується такими показниками продуктивності: несучість - 40,6 шт. на голову; маса яйця - 153,2 г; запліднюваність - 83,5\%; виводимість - 71,8\%; жива маса гусей в 9-тижневому віці - самці 4,05 кг, самки - 3,67 кг; збереженість $87,0 \%$.

2. Помісні гуси ОБ х легарт (II група) мали нижчі показники продуктивності: за несучістю на 2,9\%, проте мали вищу запліднюваність - 0,5\%; виводимість - 1,5\%; живу масу гусей в 9-тижневому віці: самці - на $6,7 \%$, самки - 4,6\%; збереженістю - 2,0\%; при вищій масі яйця на 2,1\%.

3. Гуси оброшинської сірої породної групи (III група) характеризуються такими показниками продуктивності: несучість - 40,6 шт. на голову; маса яйця 153,2 г; запліднюваність - 83,0\%; виводимість $71,0 \%$; жива маса гусей в 9-тижневому віці - самці 4,05 кг, самки - 3,67 кг; збереженість - 87,0\%.

4. Помісні гуси ОС х ВC (IV група) характеризуються відповідно нижчими показниками: за несучістю на 2,9\%, проте вони мали вищу запліднюваність $0,5 \%$; виводимість - $1,5 \%$; живу масу гусей в 9тижневому віці: самці - на 6,7\%, самки - 4,6\%; збереженість - 2,0\%; при вищій масі яйця на 4,5\%.

5. Статистично вірогідної різниці між групами за вмістом перо-пухової сировини нами не виявлено.

Перспективи подальших досліджень. В майбутньому ми плануємо проводити дослідження із наявним поголів'ям гусей для ще кращої консолідації бажаних ознак продуктивності та відтворювальних здатностей гусей, та значного збільшення поголів'я цих птахів в господарствах усіх форм власності в західному регіоні.

\section{References}

Aghdam Shahryar, H., \& Lotfi, A. (2015). The effect of peripheral administration of ghrelin on the performance of growing geese. Archives Animal Breeding, 58(1), 211-216. doi: 10.5194/aab58-2112015.
Bozhko, P.G. (1989). Gusevodstvo Har'kovshhiny. Pticevodstvo, 10, 56-57 (in Russian).

Orishchuk, O.S., Ruban, N.A., Tsap, S.V., Mykytiuk, V.V., \& Darmohray, L.M. (2017). Productivity and slaughter index of young gees feeding of soybean lecithin and sunflower. Scientific Messenger LNUVMBT named after S.Z. Gzhytskyj, 19(74), 3843. doi: 10.15421/nvlvet7409.

Petriv, M., Sloboda, L., \& Slobod, O. (2017). Intensity of growth and development of the young of obroshyno gray geese generation crossed with big gray breed geese, f ii generation, crossed with geese big seed of breed. Scientific Messenger LNUVMBT named after S.Z. Gzhytskyj, 19(74), 219-223. https://nvlvet.com.ua/index.php/journal/article/view/1 136.

Petriv, M.D. (2016). Pleminni ta produktyvni yakosti obroshynskykh sirykh i bilykh husei pry yikh rozvedenni. Visnyk ahrarnoi nauky, 1, 41-44 (in Ukrainian).

Petriv, M.D., Sloboda, L.Ia., \& Sloboda, O.M. (2018). Meat quality of Obroshyno grey geese while their cultivation. Ukrainian Journal of Veterinary and Agricultural Sciences, 1(2), 7-10. doi: 10.32718/ ujvas1-2.02.

Sedilo, H.M. (2014). Zabiini pokaznyky obroshynskykh husei pry yikh rozvedenni "v sobi". Peredhirne ta hirske zemlerobstvo i tvarynnytstvo, 56(II), 35-28 (in Ukrainian).

Sloboda, L., \& Sloboda, O. (2018). Reproductive qualities, exterior features and the quality of the pery of obroshinsky gray geese at their dissolution "inside". Scientific Messenger of Lviv National University of Veterinary Medicine and Biotechnologies, 20(84), 137-142. doi: 10.15421/nvlvet8425.

Solé, M., Negro, S., Membrillo, A., Peña, F., Domenech, V., Verona, J. C., Rubí, M., Valera, M., \& Molina, A. (2016). Association analysis of g.68G $\rightarrow$ A SNP in CAPN1 gene with carcass and meat quality traits in goose raised in organic dehesa, Arch. Anim. Breed., 59, 423-428, doi: 10.5194/aab-59-423-2016.

Zaplatynsky, V.S. (2017). The correlation between dimensional characteristics, live weight and fluff and feather level of obroshynska gray and obroshynska white natural groups geese. Scientific Messenger LNUVMBT named after S.Z. Gzhytskyj, 19(74), 156160. doi: $10.15421 /$ nvlvet7435.

Vlizlo, V.V. (2012). Laboratorni metody doslidzhen u biolohii, tvarynnytstvi ta veterynarnii medytsyni: dovidnyk. Lviv (in Ukrainian). 